\title{
Lingual Thyroid Ectopia: Diagnostic SPECT/CT Imaging and Radioactive lodine Treatment
}

\author{
Arpit Gandhi, Ka Kit Wong,, ${ }^{1,2}$ Milton D. Gross, ${ }^{1,2}$ and Anca M. Avram ${ }^{1}$
}

Background: Lingual thyroid is a rare abnormality of thyroid development that is usually treated conservatively with levothyroxine replacement. Rarely, it becomes large enough to cause obstructive symptoms in the oral cavity, requiring definitive treatment.

Patient Findings: This study reports on three patients with lingual thyroid treated with radioactive iodine-131 $\left({ }^{131} \mathrm{I}\right)$ with successful radioablation of their ectopic thyroid tissues. Measurement of 24-hour radioactive iodine uptake within thyroidal tissues and hybrid single-photon emission computed tomography/computed tomography imaging using either iodine-123 or technetium-99m pertechnetate scans were performed in all patients demonstrating the location and size of lingual thyroid and absence of an orthotopic thyroid gland.

Summary: The aim of this study was to describe nonsurgical management of obstructive lingual thyroid tissue with ${ }^{131}$ I therapy for lingual thyroid radioablation. Patients were prepared with a low-iodine diet and levothyroxine withdrawal prior to radioablation for optimizing ${ }^{131}$ I uptake in ectopic thyroid tissues. Hybrid single-photon emission computed tomography/computed tomography measurement of anatomic size of lingual thyroid tissue and radioactive iodine uptake guided the selection of therapeutic doses, resulting in administration of $10.7,17.5$, and $15.4 \mathrm{mCi}$ of ${ }^{131} \mathrm{I}$, respectively. There were no post-therapy complications, and clinical follow-up demonstrated resolution of obstructive oropharyngeal symptoms.

Conclusions: Ectopic lingual thyroid tissue is rarely associated with obstructive oropharyngeal symptoms due to progressive enlargement. Radioiodine therapy with ${ }^{131} \mathrm{I}$ is an effective treatment modality for ablation of ectopic thyroid tissue as an alternative to surgery.

\section{Introduction}

$\mathbf{L}$ INGUAL THYROID IS A RARE congenital disorder of thyroid development, accounting for $90 \%$ of cases of ectopic thyroid tissue $(1,2)$. It is four times more prevalent in women (3), and often is diagnosed at birth or in early childhood (4). In $75 \%$ of cases, there is absence of the orthotopic thyroid gland, with lingual thyroid tissue as the only source of thyroid hormone (1). Persons with lingual thyroid are usually asymptomatic, and management is conservative. In approximately $70 \%$ of cases, lingual thyroid is associated with hypothyroidism, requiring thyroid hormone replacement, resulting in involution of ectopic glandular thyroid tissue at the tongue base (5-7). However, a minority present with obstructive oropharyngeal symptoms, such as cough, pain, dysphagia, dysphonia, and dyspnea, if the ectopic thyroid tissue becomes sufficiently large, despite adequate thyroxine replacement and suppression of thyrotropin (TSH) (1).

This study reports on three patients with lingual thyroid referred to the authors' division for consideration of radioac- tive iodine-131 ( ${ }^{131}$ I) therapy following endocrine or otolaryngology surgical consultation. The University of Michigan Institutional Review Board approved the retrospective review of medical records. There were no immediate post-radioiodine therapy complications, and in two patients, there was successful ablation of their ectopic thyroid tissue with radioactive ${ }^{131}$ I, thereby avoiding surgery. The third patient had surgical resection of a thyroglossal duct mass followed by radioiodine treatment of a lingual thyroid with ectopic tissue uptake depicted on the post-radioiodine therapy ${ }^{131}$ I scan.

\section{Methods of Calculation}

As part of the diagnostic evaluation, thyroid scans were performed with either iodine-123 $\left({ }^{123} \mathrm{I}\right)$ or technetium-99m $\left({ }^{99 \mathrm{~m}} \mathrm{Tc}\right)$ radiotracers using hybrid single-photon emission computed tomography/computed tomography (SPECT/CT) that confirmed the presence of a lingual thyroid and absence of an orthotopic thyroid gland in all patients. One patient also had concurrent subhyoid ectopic thyroid tissue. Measurement of

\footnotetext{
${ }^{1}$ Nuclear Medicine/Radiology, University of Michigan, Ann Arbor, Michigan.

${ }^{2}$ Nuclear Medicine Service, Department of Veterans Affairs Health System, Ann Arbor, Michigan.
} 
24-hour radioactive iodine uptake (RAIU) was performed in all patients. The target volume of therapy was determined by tridimensional anatomic measurements (Anterior-Posterior $($ A-P) $\times$ Transverse $(\mathrm{TV}) \times$ Cranial-Caudal $(\mathrm{C}-\mathrm{C})$ ) of lingual thyroid tissue using the CT component of the SPECT/CT scans, based on an ellipsoid $(\pi / 6 \times \mathrm{A}-\mathrm{P} \times \mathrm{TV} \times \mathrm{C}-\mathrm{C})$ model $(8)$. In clinical practice, soft-tissue density is approximated at $1 \mathrm{~g} / \mathrm{mL}$. Therefore, the volumetric measurements of the lingual thyroid were approximated to the thyroid tissue mass.

A therapeutic ${ }^{131}$ I activity was used calculated to deliver a dose of $0.3 \mathrm{mCi}$ per gram of thyroid tissue retained in the lingual thyroid gland at 24 hours by the formula:

$$
\underset{\text { Therapeutic }}{\text { activity }(\mathrm{mCi})}=\frac{0.3 \mathrm{mCi} \times \text { target thyroid tissue mass }(\mathrm{g})}{\text { RAIU }}
$$

According to this formula, the prescribed therapy ${ }^{131}$ I dose is directly proportional to the mass of thyroid tissue and inversely proportional to the RAIU (9). The intended dosing factor of $0.3 \mathrm{mCi}$ per gram of thyroid tissue is a strategy used in pediatric hyperthyroidism when there is an emphasis on achieving successful RAI treatment with a single therapy administration (10). To optimize RAIU, patients were prepared with a low-iodine diet for one week prior to RAIU and subsequent administration of ${ }^{131} \mathrm{I}$ therapy with the intent of maximizing radioiodine uptake and reducing the therapeutic ${ }^{131}$ I dose. In addition, levothyroxine (LT4) withdrawal for four weeks was performed with the goal of increasing the ${ }^{131}$ I uptake and the retention in the lingual thyroid tissue. Liquid ${ }^{131}$ I was used for treatment, with therapeutic ${ }^{131}$ I doses prepared on-site by the nuclear pharmacist.

The information obtained by SPECT/CT on the size of the lingual thyroid tissue and the 24-hour RAIU measurement within the glandular tissue may contribute valuable data that can guide selection of the therapeutic ${ }^{131} \mathrm{I}$ dose, by highlighting potential problems with RAI treatment (e.g., very low uptake or very large ectopic deposits). In two patients, the actual administered RAI dose used was higher than the calculated dose. Influenced by prior reports that described the need for significantly higher doses of ${ }^{131} \mathrm{I}$ administration for treatment of lingual thyroids, and with the intention of achieving rapid resolution of oropharyngeal obstructive symptoms, the treating clinician used a higher dose than indicated by the calculations to maximize the chance of successful treatment with a single RAI therapy. Dosing of RAI based solely on calculations obtained from SPECT/CT information still needs to be further investigated in this rare condition.

\section{Patients}

\section{Patient 1}

A 20-year-old woman presented with six to eight months of progressive dysphagia, intermittent odynophagia, and frequent upper respiratory infections. Her past medical history was significant for diagnosis of a lingual thyroid at three years of age. Evaluation for a sore throat at the time revealed the presence of a mass at the base of the tongue, which was proven to be thyroid tissue by direct biopsy. She was hypothyroid and was placed on LT4 treatment. She had an uneventful clinical course throughout her childhood and adolescence, but in early adulthood presented with progressive obstructive oropharyngeal symptoms with difficulties swallowing some solid foods, including tablets, which tended to "stick" at the base of the tongue. She did not report problems with liquids. After initial evaluation by an otolaryngologist, she was referred for nonsurgical management of the lingual thyroid. Physical examination revealed the presence of an approximately $2.0 \mathrm{~cm}$ fleshy mucosal nodule in the midline of the posterior tongue that displaced the uvula to the right. The mass was easily visualized when the patient protruded her tongue. Her TSH was $1.1 \mathrm{mIU} / \mathrm{L}$, free triiodothyronine (fT3) was $2.7 \mathrm{pg} / \mathrm{mL}$, and free thyroxine (fT4) was $1.43 \mathrm{ng} / \mathrm{dL}$ while taking $0.075 \mathrm{mg}$ of LT4 daily. She underwent four weeks of LT4 withdrawal, resulting in endogenous hypothyroidism and an elevation of her TSH to $15.0 \mathrm{mIU} / \mathrm{L}$. A thyroid scan performed after administration

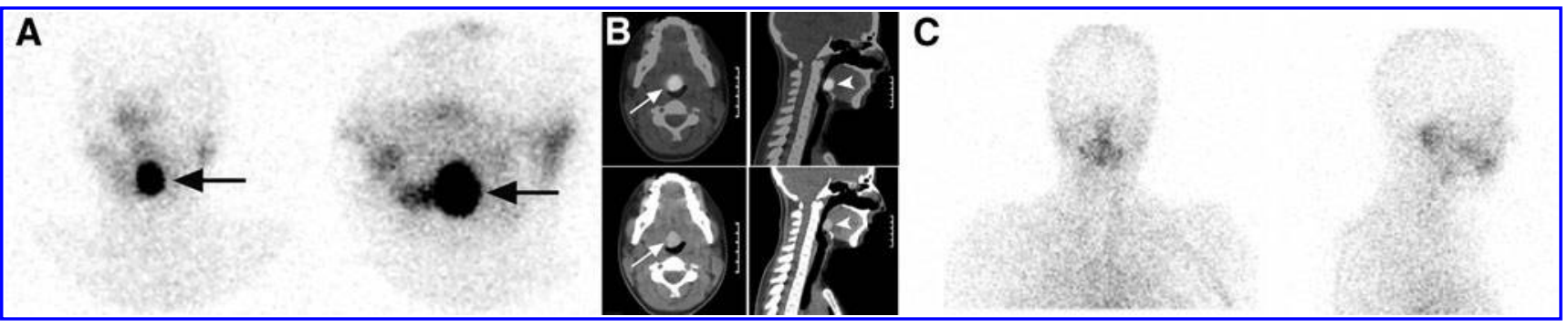

FIG. 1. Baseline radioiodine (RAI) scintigraphy after oral administration of $0.4 \mathrm{mCi}$ of iodine-123 $\left({ }^{123} \mathrm{I}\right)$ was performed at 4 and 24 hours. (A) Planar (left) and pinhole (right) images demonstrate absence of uptake in the expected location of the thyroid gland and an intense focus of RAI uptake in the midline of the upper neck (arrows) overlying the oral cavity. (B) ${ }^{123} \mathrm{I}$ single-photon emission computed tomography/computed tomography (SPECT/CT) fusion images, axial (upper left), and sagittal (upper right) performed at four hours for anatomical correlation precisely localized radioiodine uptake in a softtissue mass in the base of the tongue (arrows and arrowheads), with higher attenuation than surrounding soft tissue on the corresponding CT axial (lower left) and sagittal (lower right). Findings were consistent with a diagnosis of lingual thyroid. Dimensions of lingual thyroid tissue of $1.9 \mathrm{~cm} \times 1.7 \mathrm{~cm} \times 2.4 \mathrm{~cm}$ (calipers have $1 \mathrm{~cm}$ gradations) resulted in a calculated volume of $4.1 \mathrm{~g}$ of glandular tissue. The 24 -hour ${ }^{123} \mathrm{I}$ thyroid uptake was measured at $10.3 \%$. (C) Six-month follow-up technetium-99m $\left({ }^{99 \mathrm{~m}} \mathrm{Tc}\right)$ pertechnetate thyroid scan after RAI therapy, anterior (left) and sagittal (right) projection tomographic images obtained at 20 minutes after intravenous radiotracer administration demonstrate resolution of prior uptake at the posterior oral cavity compatible with successful ablation of lingual thyroid. 
of ${ }^{123}$ I demonstrated focal uptake in the oral cavity (Fig. 1A), which on SPECT/CT localized to a high attenuation soft-tissue mass at the base of tongue measuring $1.9 \mathrm{~cm} \times 1.7 \mathrm{~cm} \times 2.4 \mathrm{~cm}$ (Fig. 1B), resulting in a calculated volume of $4.0 \mathrm{~g}$ of glandular tissue. There was absence of an orthotopic, functioning thyroid gland. The 24 -hour ${ }^{123} \mathrm{I}$ uptake was $10.3 \%$. The patient received $10.7 \mathrm{mCi}$ of ${ }^{131} \mathrm{I}$ for ablation of her lingual thyroid (calculated activity $11.7 \mathrm{mCi}$ ).

After radioiodine therapy, the patient resumed therapy with LT4. At a six-month follow-up, she was well and noted resolution of her previously reported obstructive oropharyngeal symptoms. Physical examination revealed near complete disappearance of the lingual thyroid mass. The uvula had returned to a midline position. A repeat ${ }^{99 \mathrm{~m}} \mathrm{Tc}$ pertechnetate thyroid scan depicted interval resolution of lingual thyroid tissue (Fig. 1C).

\section{Patient 2}

A 53-year-old woman presented with globus sensation and a choking sensation when lying supine that was present for the past two years. She was diagnosed with hypothyroidism at the age 40 years, and started on LT4. At the time of evaluation, she was on $0.112 \mathrm{mg}$ daily. Physical examination revealed an unremarkable oral cavity and oropharynx. Indirect laryngoscopy revealed a round, symmetric midline mass at the base of the tongue. No thyroid gland was palpable in the lower neck. A SPECT/CT ${ }^{99 \mathrm{~m}} \mathrm{Tc}$ pertechnetate thyroid scan demonstrated focal radiotracer accumulation at the base of the tongue, corresponding to a rounded, high attenuation, $2.5 \mathrm{~cm}$ tongue base mass without evidence of normal thyroid tissue in the expected anatomic location at the base of the neck.

A four-week LT4 withdrawal protocol produced subclinical hypothyroidism (TSH $7.81 \mathrm{mIU} / \mathrm{L} ; \mathrm{fT} 40.72 \mathrm{ng} / \mathrm{dL}$; fT3 $2.4 \mathrm{pg} /$ $\mathrm{mL}$ ) and ${ }^{123}$ I thyroid scan depicted radioactivity in lingual thyroid tissue measuring $2.5 \mathrm{~cm} \times 1.8 \mathrm{~cm} \times 2.4 \mathrm{~cm}$, resulting in a calculated volume of $5.6 \mathrm{~g}$ of glandular tissue. A 24 -hour ${ }^{123} \mathrm{I}$ uptake was $13.5 \%$. The patient was treated with $17.5 \mathrm{mCi}^{131} \mathrm{I}$ (calculated activity $12.6 \mathrm{mCi}$ ). She resumed LT4 replacement shortly after RAI therapy. At six months post-radioiodine therapy, she reported decreased globus sensation. A SPECT/ $\mathrm{CT}{ }^{99 \mathrm{~m}} \mathrm{Tc}$ pertechnetate thyroid scan showed resolution of the increased radiotracer uptake in the lingual thyroid tissue, with a $65 \%$ interval reduction in size of the soft-tissue nodule at the tongue base, displaying a CT attenuation similar to that of surrounding tissues, consistent with residual post-therapy scar tissue.

\section{Patient 3}

A 38-year-old woman presented to medical attention with a one-year history of globus sensation and progressive dysphagia with both solids and liquids. CT of the neck demonstrated two homogenously enhancing soft-tissue nodules: the first was located anterior and parasagittal to the right thyroid cartilage, and the second was at the midline of the tongue base. $\mathrm{A}^{99 \mathrm{~m}} \mathrm{Tc}$ pertechnetate thyroid scan performed five months later revealed increased radiotracer activity corresponding to these soft-tissues nodules, consistent with thyroid ectopy (Fig. 2). The anterior right paratracheal ectopic thyroid tissue nodule measured $3.9 \mathrm{~cm} \times 2.7 \mathrm{~cm} \times 1.5 \mathrm{~cm}$, and the lingual thyroid measured $1.4 \mathrm{~cm} \times 1.1 \mathrm{~cm} \times 1.2 \mathrm{~cm}$ (calculated volume $0.97 \mathrm{~g}$ of glandular tissue). There was absence of an orthotopic, functioning thyroid gland. Yet, the patient was euthyroid. She underwent surgical excision of the right paratracheal ectopic thyroid tissue. However, the endocrine surgeon deferred operating on the lingual thyroid because of potential comorbidities (pain, bleeding, infection) associated with tongue surgery. Instead, the patient was referred for RAI ablation. Four weeks after surgery, the patient's TSH was $71 \mathrm{mIU} / \mathrm{L}$, and her 24 hour ${ }^{131} \mathrm{I}$ uptake was $3.9 \%$. After low-iodine diet preparation, she was treated with $15.4 \mathrm{mCi}$ of ${ }^{131} \mathrm{I}$ (calculated activity 7.4 $\mathrm{mCi}$ ). Following ${ }^{131} \mathrm{I}$ treatment, thyroid hormone replacement was started with $0.15 \mathrm{mg}$ of LT4 daily. A post-therapy ${ }^{131} \mathrm{I}$ thyroid scan performed five days following treatment showed intense focal radiotracer uptake at the base of the tongue, consistent with RAI targeting the lingual thyroid tissue.

The patient demographics, presenting symptoms, imaging, RAI treatment, and outcomes are summarized in Table 1.

\section{Discussion}

Ectopic thyroid tissue is a rare developmental anomaly affecting embryogenesis of the thyroid in its descent from the

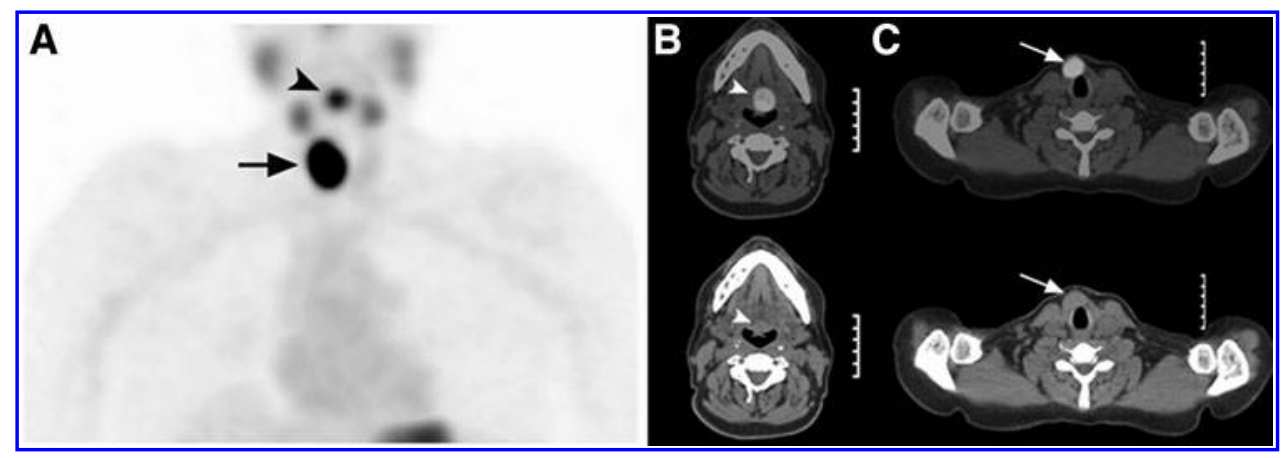

FIG. 2. Baseline scintigraphy was performed 20 minutes after intravenous administration of $5 \mathrm{mCi}$ of ${ }^{99 \mathrm{~m}} \mathrm{Tc}$ pertechnetate. (A) anterior projection tomographic image demonstrates two foci of uptake: one at the level of the oral cavity (arrowhead), and one at the neck (arrow). (B) ${ }^{99 \mathrm{~m}} \mathrm{Tc}$ pertechnetate SPECT/CT fusion axial image (upper) precisely localized radiotracer uptake in a soft-tissue mass in the base of the tongue (arrowheads) measuring $1.4 \mathrm{~cm} \times 1.1 \mathrm{~cm} \times 1.2 \mathrm{~cm}$, with higher attenuation than surrounding soft tissue on the corresponding axial CT (lower). (C) SPECT/CT fusion axial image (upper) and axial CT (lower) localized the second focus of radiotracer uptake to a paratracheal soft tissue mass (arrows) measuring $1.8 \mathrm{~cm} \times 2.6 \mathrm{~cm} \times 2.1 \mathrm{~cm}$ (calipers have $1 \mathrm{~cm}$ gradations). 
Table 1. Patient Demographics, Presenting Symptoms, Radionuclide Imaging, Radioiodine TREaTMEnt, AND OUtCOMES

\begin{tabular}{|c|c|c|c|}
\hline & Patient 1 & Patient 2 & Patient 3 \\
\hline Age (years) & 20 & 53 & 38 \\
\hline Thyroid function status & $\begin{array}{l}\text { Hypothyroidism since age of } \\
3 \text { years }\end{array}$ & $\begin{array}{l}\text { Hypothyroidism since the age } \\
\text { of } 40 \text { years }\end{array}$ & Euthyroid \\
\hline Presenting symptoms & $\begin{array}{l}\text { 6-8 months of progressive } \\
\text { dysphagia, odynophagia, } \\
\text { and frequent upper } \\
\text { respiratory infections }\end{array}$ & $\begin{array}{l}\text { 2-year history of globus } \\
\text { sensation and sensation of } \\
\text { choking when lying supine }\end{array}$ & $\begin{array}{l}\text { 1-year history of globus } \\
\text { sensation and dysphagia }\end{array}$ \\
\hline Thyroid scan & ${ }^{123} \mathrm{I}$ SPECT/CT & ${ }^{123} \mathrm{I}$ SPECT/CT & $\begin{array}{l}{ }^{99 \mathrm{~m}} \text { Tc pertechnetate } \\
\text { SPECT/CT }\end{array}$ \\
\hline Findings & $\begin{array}{l}\text { Hyperdense tongue base mass } \\
(1.9 \mathrm{~cm} \times 1.7 \mathrm{~cm} \times 2.4 \mathrm{~cm}) \\
\text { with focal }{ }^{123} \mathrm{I} \text { uptake } \\
\text { Absence of orthotopic } \\
\text { thyroid }\end{array}$ & $\begin{array}{l}\text { Hyperdense tongue base mass } \\
(2.5 \mathrm{~cm} \times 1.8 \mathrm{~cm} \times 2.4 \mathrm{~cm}) \\
\text { with focal }{ }^{123} \mathrm{I} \text { uptake } \\
\text { Absence of orthotopic } \\
\text { thyroid }\end{array}$ & $\begin{array}{l}\text { Hyperdense tongue base mass } \\
(1.4 \mathrm{~cm} \times 1.1 \mathrm{~cm} \times 1.2 \mathrm{~cm}), \\
\text { a right anterior paratracheal } \\
\text { mass }(1.8 \mathrm{~cm} \times 2.6 \mathrm{~cm} \\
\times 2.1 \mathrm{~cm}) \text { with increased } \\
99 \mathrm{~m} \text { Tc pertechnetate uptake } \\
\text { Absence of orthotopic } \\
\text { thyroid }\end{array}$ \\
\hline 24-hour ${ }^{123}$ I uptake & $10.3 \%$ & $13.5 \%$ & $3.9 \%\left({ }^{131}\right.$ I uptake $)$ \\
\hline $\begin{array}{l}\text { Pre-radioiodine ablation } \\
\text { management }\end{array}$ & $\begin{array}{l}\text { 4-week withdrawal from LT4, } \\
\text { and 1-week low-iodine diet }\end{array}$ & $\begin{array}{l}\text { 4-week withdrawal from LT4, } \\
\text { and 1-week low-iodine diet }\end{array}$ & $\begin{array}{l}\text { Surgical excision of } \\
\text { thyroglossal duct } \\
\text { paratracheal tissue } 2 \\
\text { months earlier, then 1-week } \\
\text { low-iodine diet }\end{array}$ \\
\hline${ }^{131}$ I treatment dose & $10.7 \mathrm{mCi}$ (liquid) & $17.5 \mathrm{mCi}$ & $15.4 \mathrm{mCi}$ (liquid) \\
\hline Outcome & $\begin{array}{l}\text { Interval resolution of lingual } \\
\text { thyroid uptake at 6-month } \\
\text { follow-up }\end{array}$ & $\begin{array}{l}65 \% \text { reduction in size of } \\
\text { lingual thyroid, with } \\
\text { absence of uptake of }{ }^{99 \mathrm{~m}} \mathrm{Tc} \\
\text { at 6-month follow-up }\end{array}$ & $\begin{array}{l}\text { Intense lingual thyroid uptake } \\
\text { on 4-day post-treatment } \\
{ }^{131} \text { I scan }\end{array}$ \\
\hline
\end{tabular}

${ }^{123} \mathrm{I}$, iodine-123; ${ }^{131} \mathrm{I}$, iodine-131; ${ }^{99 \mathrm{~m}} \mathrm{Tc}$, technetium-99m; LT4, levothyroxine; SPECT/CT, single-photon emission computed tomography/computed tomography.

primitive foregut location to the final pretracheal location in the neck (1). The thyroid is the first endocrine gland to develop in the embryo. At approximately the third to fourth gestational week, the primordium of the medial part of the thyroid forms as an endodermal thickening of the midline floor of the pharynx between the first and second pharyngeal arches (11-13). Primitive thyroid cells derived from the thyroid anlage penetrate the underlying mesenchymal tissue, migrating caudally anterior to the hyoid and the laryngeal cartilages to reach the normal pretracheal position around the seventh gestational week (2), with fetal thyroid hormone detectable by the 11th gestational week (13). The proximal segment of the thyroglossal duct regresses between the 5th and 10th weeks of development, leaving a permanent pit at the dorsum of the tongue, known as the foramen cecum $(14,15)$.

The prevalence of thyroid ectopia is estimated at 1/100,000-300,000 persons (1). Reported locations of ectopic thyroid tissue include lingual, intralingual, sublingual, thyroglossal duct cyst, low neck ectopia, intratracheal, esophageal, mediastinal, aortic, intracardiac, and abdominal ectopias. Lingual thyroid is the most common type, accounting for $90 \%$ of reported cases (1). Ectopic lingual thyroid tissue was first reported in $1869(3,16,17)$. About $75 \%$ of patients with a lingual thyroid lack thyroid tissue at the normal cervical location, and up to $70 \%$ are hypothyroid, although hyperthyroidism has rarely been reported $(1,7)$. Ectopic thyroid tissue often has functional insufficiency, and undergoes compensatory enlargement, seen more commonly in patients who have increased physiological requirement of thyroxine during periods of active growth, puberty, and pregnancy. In the case of a lingual thyroid, this increase in size may result in clinical symptoms of dysphagia, dysphonia, or dyspnea. Occasionally, obstructive sleep apnea and difficulties with intubation have been noted in relation to lingual thyroid tissue, whereas malignancy is rare (1).

Ectopic thyroid tissue is diagnosed using ultrasound (US), $\mathrm{CT}$, magnetic resonance imaging (MRI), fine-needle aspiration biopsy, and radionuclide scanning, performed in the context of differential diagnosis of a neck mass or during the workup of (congenital) hypothyroidism $(1,18,19)$. The presence of normal thyroid tissue in the neck is easily ascertained with US or CT. Radionuclide scanning is virtually diagnostic, either with ${ }^{99 \mathrm{~m}} \mathrm{Tc}$ pertechnetate, ${ }^{123} \mathrm{I}$, or ${ }^{131} \mathrm{I}$ through uptake of this radionuclide by the sodium-iodide symporter (NIS). This allows the thyroid origin of the ectopic tissue to be confirmed, and whether there is an orthotopic thyroid gland present to be assessed (1). The frequency of ectopic thyroid tissue was studied in 11,905 thyroid scans over a period of five years for investigation of neck masses or hypothyroidism. The scans were grouped as (i) athyreosis with absence of discernable thyroid tissue, (ii) a single visualized site of ectopic thyroid tissue, or (iii) dual ectopia, defined as the simultaneous presence of two distinct populations of ectopic thyroid tissue (20). There were 121 patients with thyroid dysgenesis: 32 athyroid cases, 83 with a single site of ectopic thyroid tissue, and 6 with dual ectopic thyroid tissue 
(2). The authors reviewed cases of dual ectopic thyroid tissue in the neck, noting 42 published cases, comprised of lingual thyroid in $33 \%$, sublingual in $27 \%$, and subhyoid in $22 \%$ sites, with most patients $<30$ years old. Of these, $38 \%$ were euthyroid, $33 \%$ hypothyroid, and $21 \%$ had subclinical hypothyroidism (2). Typically planar or pinhole scintigraphic imaging is sufficient for diagnosis, although the benefit of 3D SPECT imaging for lingual thyroid has been reported (21). Both ${ }^{99 \mathrm{~m}} \mathrm{Tc}$ pertechnetate SPECT/CT $(7,22,23)$ or ${ }^{123} \mathrm{I}$ SPECT/CT scans to depict radioiodine uptake within lingual thyroid have been reported $(24,25)$. In one case SPECT/CT clearly demonstrated ${ }^{99 \mathrm{~m}} \mathrm{Tc}$ pertechnetate uptake within a dual thyroid ectopia (lingual and sublingual sites) with absence of an orthotopic thyroid, similar to the third patient in this study (23).

Medical management with thyroid hormone replacement has been used to suppress the growth of lingual thyroid tissue, and to achieve shrinkage of ectopic thyroid tissue, thus providing relief of obstructive symptoms. Surgery is the traditional definitive treatment considered when conservative management is unsuccessful and if the patient develops oropharyngeal obstruction, bleeding, sudden enlargement of the lingual thyroid, or if there is evidence of malignancy (1). The intent of treatment of lingual thyroid glands consists in achieving a measurable reduction in the size of the gland with the goal to relieve symptoms such as dysphagia, odynophagia, or dyspnea. A range of surgical approaches have been described in the literature (26-28), along with other targeted therapies (29). Surgical excision has been described via transoral, lateral pharyngotomy, and suprahyoid approaches. The trans-oral approach is ideally suited for small lingual thyroid masses located superior to the hyoid. Occasionally a mandibulotomy and midline tongue splitting approach is required for larger lesions $(30,31)$. Bleeding and pain are common, as is post-surgical scar in excision of larger lesions. Trans-oral robotic surgery (TORS) and transposition flaps to shift the lingual thyroid to the lateral oral floor are newer surgical techniques $(1,32)$. Successful use of TORS was reported in three symptomatic lingual thyroid patients, with resolution of symptoms and satisfactory cosmetic results, and no perioperative complications or significant bleeding (33). Other newer targeted treatments such as CO2 laser (34) and radiofrequency ablation (35) have been reported without bleeding complications.

RAI is another treatment option for symptomatic lingual thyroids (1), with the first case of RAI treatment reported by Schilling et al. in 1950 (36,37). In 1955, two siblings with lingual thyroid were treated as infants with RAI mixed in milk, with resultant shrinkage of their masses at the base of the tongue and resolution of symptoms (38). However, since that time, RAI therapy has not been widely used due to concerns regarding radiation exposure in younger individuals, the potential of possible airways obstruction after RAI administration, and concerns about delivering sufficient RAI activity to ablate the ectopic thyroid tissue. Despite these concerns, there are multiple reports of successful RAI treatment of lingual thyroid. Danner et al. reviewed their experience over a six-year period, and found two patients with lingual thyroid glands treated successfully with $30 \mathrm{mCi}$ and $85 \mathrm{mCi}{ }^{131} \mathrm{I}$ (36). These patients had complete resolution of symptoms at two months after RAI treatment, with no airway compromise and subsequent development of hypothyroidism (follow-up to 18 and 24 months). Iglesias et al. reported a patient treated with $20 \mathrm{mCi}$ of ${ }^{131} \mathrm{I}$ in two divided $10 \mathrm{mCi}$ doses separated by nine months (39). The authors did not specify the therapeutic strategy for RAI dose fractionation, whether this represented a failure of the first dose of ${ }^{131} \mathrm{I}$ therapy, or if the RAI therapy was planned as two separate doses from the outset. Park et al. reported successful treatment of a lingual thyroid with an unspecified ${ }^{131}$ I dose (24). A 27 -year-old woman with a large $8 \mathrm{~cm} \times 6 \mathrm{~cm}$ biopsyconfirmed submental ectopic thyroid mass was imaged with ${ }^{99} \mathrm{~m}$ Tc pertechnetate and a correlative MRI. She was treated successfully with $26 \mathrm{mCi}{ }^{131} \mathrm{I}$, leading to resolution of swelling and compressive symptoms after three months, and she was well at two years of follow-up on thyroid hormone replacement (3). A 48-year-old woman with a $3 \mathrm{~cm}$ lingual thyroid presenting with obstructive sleep apnea and intermittent dyspnea and dysphagia was imaged with ${ }^{123}$ I SPECT/ CT and was found to have a 24-hour ${ }^{123} \mathrm{I}$ uptake of $14.5 \%$. Due to high surgical risk, an alternative approach to surgical excision was preferred, and $30 \mathrm{mCi}$ of ${ }^{131} \mathrm{I}$ was used to ablate the lingual thyroid successfully, with an $83 \%$ reduction in the volume of the lingual thyroid and resolution of symptoms at two years of follow-up (24).

This study contributes an additional three cases to the prior nine cases reported in the literature. This report illustrates the use of SPECT/CT imaging for the diagnosis and planning of RAI therapy for ablation of ectopic lingual thyroid. Two of the patients returned for clinical follow-up: one patient reported resolution of oropharyngeal obstructive symptoms, and the other patient reported significant improvement of globus sensation. Follow-up ${ }^{99 \mathrm{~m}} \mathrm{Tc}$ pertechnetate scintigraphy obtained at six months after ${ }^{131}$ I therapy demonstrated successful ablation of all lingual thyroid tissue. The third patient had two ectopic foci with surgical excision of a subhyoid thyroid mass followed by RAI treatment of a lingual thyroid. A RAI post-therapy scan depicted lingual thyroid, although the patient was lost to follow-up. All three patients reported in this study received oral liquid ${ }^{131}$ I formulation for radioablation. The therapeutic ${ }^{131} \mathrm{I}$ formulation (i.e., liquid vs. capsule) used in other reported series is unknown, as is whether problems were encountered in administering RAI to patients with thyroid ectopia.

Each patient had specialist thyroid surgical consultation, with either an endocrine or otolarygology surgeon, and each case was discussed at multidisciplinary tumor boards. Lingual thyroid is a rare condition, it is not known how many surgeries (if any) were performed for lingual thyroids during the same six-year time period at the authors' institution. The decision to select patients for RAI treatment rather than surgery was based on numerous factors, including symptomatology, location of ectopic thyroid tissues, comorbidities, perceived concerns of complications of RAI versus surgery, suitability for robotic surgery via the transoral route (33), RAIU values, and willingness to adhere to post-RAI therapy radiation safety precautions. Patient preference played an important role in final decision making. Cases reported in the literature are characterized by variable approaches for the selection of RAI treatment. They report a range of lingual thyroid uptake values, and do not specify methods for calculation of therapeutic ${ }^{131}$ I activities that ranged between 20 and $85 \mathrm{mCi}$. In these cases, the estimation of lingual thyroid tissue volume was obtained from separately acquired CT or MRI imaging 
studies. The authors' experience is that hybrid SPECT/CT can give valuable information regarding size, location, the nature of the ectopic thyroid tissue, and RAIU values, which can then assist in the selection of a therapeutic ${ }^{131}$ I activity using wellestablished methods. ${ }^{99 \mathrm{~m}} \mathrm{Tc}$ pertechnetate or ${ }^{123} \mathrm{I}$ scintigraphy with SPECT/CT can also be used in the follow-up assessment of therapeutic efficacy.

\section{Conclusion}

Lingual thyroid is a rare developmental anomaly that may require size reduction when progressive enlargement of ectopic thyroid tissues causes obstructive or compressive oropharyngeal signs and symptoms. Surgery has been traditionally used to extirpate ectopic thyroid tissue at the base of the tongue. RAI treatment is a safe and effective alternative treatment to ablate lingual thyroid tissue, with marked improvement or resolution of symptoms.

\section{Author Disclosure Statement}

The authors have nothing to disclose. No competing financial interests exist.

\section{References}

1. Guerra G, Cinelli M, Mesolella M, Tafuri D, Rocca A, Amato B, Rengo S, Testa D 2014 Morphological, diagnostic and surgical features of ectopic thyroid gland: a review of literature. Int J Surg 12:S3-11.

2. Meng Z, Lou S, Tan J, Jia Q, Zheng R, Liu G, Zhu M, He Q, Li D 2014 Scintigraphic detection of dual ectopic thyroid tissue: experience of a Chinese tertiary hospital. PLoS One 9:e95686.

3. El-Shafie OT, Hussain S, Sankhla D, Woodhouse N 2014 Radioactive iodine-131 therapy in the management of ectopic thyroid tissue. Sultan Qaboos Univ Med J 14: e571-574.

4. Rahbar R, Yoon MJ, Connolly LP, Robson CD, Vargas SO, McGill TJ, Healy GB 2008 Lingual thyroid in children: a rare clinical entity. Laryngoscope 118:1174-1179.

5. Kang HC 2004 Lingual thyroid: marked response to suppression therapy. Thyroid 14:401-402.

6. Mussak EN, Kacker A 2007 Surgical and medical management of midline ectopic thyroid. Otolaryngol Head Neck Surg 136:870-872.

7. Dolezal J, Vizda J, Horacek J, Spitalnikova S 2013 Lingual thyroid: diagnosis using a hybrid of single photon emission computed tomography and standard computed tomography. J Laryngol Otol 127:432-434.

8. Muhammad W, Faaruq S, Hussain A, Kakakhail MB, Fatmi S, Matiullah 2008 Quantitative analysis of the factors responsible for over or under dose of 131 I therapy patients of hyperthyroidism. Radiat Prot Dosimetry 128:90-97.

9. Bahn RS, Burch HB, Cooper DS, Garber JR, Greenlee MC, Klein I, Laurberg P, McDougall IR, Montori VM, Rivkees SA, Ross DS, Sosa JA, Stan MN 2011 Hyperthyroidism and other causes of thyrotoxicosis: management guidelines of the American Thyroid Association and American Association of Clinical Endocrinologists. Endocr Pract 17:456-520

10. Rivkees SA, Cornelius EA 2003 Influence of iodine-131 dose on the outcome of hyperthyroidism in children. Pediatrics 111:745-749.
11. De Felice M, Di Lauro R 2004 Thyroid development and its disorders: genetics and molecular mechanisms. Endocr Rev 25:722-746.

12. De Felice M, Di Lauro R 2011 Minireview: Intrinsic and extrinsic factors in thyroid gland development: an update. Endocrinology 152:2948-2956.

13. Gillam MP, Kopp P 2001 Genetic regulation of thyroid development. Curr Opin Pediatr 13:358-363.

14. Mohebati A, Shaha AR 2012 Anatomy of thyroid and parathyroid glands and neurovascular relations. Clin Anat 25:19-31.

15. Policeni BA, Smoker WR, Reede DL 2012 Anatomy and embryology of the thyroid and parathyroid glands. Semin Ultrasound CT MR 33:104-114.

16. Hickman W 1869 Congenital tumor of the base of the tongue, pressing down the epiglottis on the larynx and causing death by suffocation sixteen hours after birth. Trans Pathol Soc Lond 20:160-161.

17. Bianco MR, La Boria A, Franco T, Ferrise P, Allegra E 2013 Ectopic lingual thyroid with vascular anomalies. Int Med Case Rep J 6:55-58.

18. Giovagnorio F, Cordier A, Romeo R 1996 Lingual thyroid: value of integrated imaging. Eur Radiol 6:105-107.

19. Guneri A, Ceryan K, Igci E, Kovanlikaya A 1991 Lingual thyroid: the diagnostic value of magnetic resonance imaging. J Laryngol Otol 105:493-495.

20. Wildi-Runge S, Stoppa-Vaucher S, Lambert R, Turpin S, Van Vliet G, Deladoey J 2012 A high prevalence of dual thyroid ectopy in congenital hypothyroidism: evidence for insufficient signaling gradients during embryonic thyroid migration or for the polyclonal nature of the thyroid gland? J Clin Endocrinol Metab 97:E978-981.

21. Spieth ME, Veluvolu P, Schmitz SL 2003 SPECT and planar imaging of a lingual thyroid gland. Clin Nucl Med 28:140-141.

22. Harisankar CN 2013 Dual ectopic thyroid in the presence of atrophic orthotopic thyroid gland in a patient with acquired hypothyroidism: Evaluation with hybrid single-photon emission computed tomography/computed tomography. Indian J Nucl Med 28:26-27.

23. Harisankar CN, Preethi GR, George M 2012 Hybrid SPECT/CT evaluation of dual ectopia of thyroid in the absence of orthotopic thyroid gland. Clin Nucl Med 37: 602-603.

24. Patel Z, Johnson L 2009 Iodine 131 ablation of an obstructive lingual thyroid. J Radiol Case Rep 3:3-6.

25. Vercellino L, Alaoui NI, Faugeron I, Berenger N, de Labriolle-Vaylet C, Hindie E, Toubert ME 2011 Lingual thyroid imaging with (1)(2)(3)I SPECT/CT. Eur J Nucl Med Mol Imaging 38:1173.

26. Rojananin S, Ungkanont K 1999 Transposition of the lingual thyroid: a new alternative technique. Head Neck 21: 480-483.

27. Skolnik EM, Yee KF, Golden TA 1976 Transposition of the lingual thyroid. Laryngoscope 86:785-791.

28. Wertz ML 1974 Management of undescended lingual and subhyoid thyroid glands. Laryngoscope 84: 507-521.

29. Dasari SD, Bashetty NK, Prayaga NS 2007 Radiofrequency ablation of lingual thyroid. Otolaryngol Head Neck Surg 136:498-499.

30. Kamat MR, Kulkarni JN, Desai PB, Jussawalla DJ 1979 Lingual thyroid: a review of 12 cases. Br J Surg 66: 537-539. 
31. Prasad KC, Bhat V 2000 Surgical management of lingual thyroid: a report of four cases. J Oral Maxillofac Surg 58: 223-227.

32. Wu ZX, Zheng LW, Dong YJ, Li ZB, Zhang WF, Zhao YF 2008 Modified approach for lingual thyroid transposition: report of two cases. Thyroid 18:465-468.

33. Park YM, Kim WS, Byeon HK, Lee SY, Kim SH 2013 A novel technique for the resection of the symptomatic lingual thyroid: transoral robotic surgery. Thyroid 23:466-471.

34. Hafidh MA, Sheahan P, Khan NA, Colreavy M, Timon C 2004 Role of CO2 laser in the management of obstructive ectopic lingual thyroids. J Laryngol Otol 118:807-809.

35. Dasari AK, Aileni KR, Rachala MR, Mallikarjun V 2014 A modified lingual arch for correction of posterior crossbite. $\underline{\mathrm{J}}$ Clin Orthod 48:791-792; quiz 795-796.

36. Danner C, Bodenner D, Breau R 2001 Lingual thyroid: iodine 131: a viable treatment modality revisited. $\underline{\mathrm{Am} \mathrm{J}}$ Otolaryngol 22:276-281.
37. Schilling JA, Karr JW, Hursh JB 1950 The treatment of a lingual thyroid with radioactive iodine. Surgery 27:130 138 , illust.

38. Springer KC 1955 Lingual thyroid; two cases in siblings diagnosed and treated with radioactive iodine. AMA Arch Otolaryngol 61:386-393.

39. Iglesias P, Olmos-Garcia R, Riva B, Diez JJ 2008 Iodine 131 and lingual thyroid. J Clin Endocrinol Metab 93:4198-4199.

Address correspondence to: Anca M. Avram, MD

University of Michigan Health System Department of Radiology, Division of Nuclear Medicine B1G505 University Hospital SPC 5028 1500 E. Medical Center Drive Ann Arbor, MI 48109-5028

E-mail: ancaa@med.umich.edu 
This article has been cited by:

1. Jed Hummel, Jason Wachsmann, Kelley Carrick, Orhan K. Oz, Dana Mathews, Fangyu Peng. 2017. Ectopic Thyroid Tissue in the Mediastinum Characterized by Histology and Functional Imaging with I-123 SPECT/CT. Case Reports in Radiology 2017, 1-5. [Crossref]

2. Vincenzo Consalvo, Gerarda Barbieri, Amalia Rosaria Rita Rossetti, Mafalda Romano, Rosaria Contieri, Salvatore Tramontano, Carmela Rescigno, Massimo Infranzi, Domenico Lombardi. 2017. Follicular adenoma in ectopic thyroid. A case-report. International Journal of Surgery Case Reports 40, 94-96. [Crossref] 